\title{
THE OPERATIVE TREATMENT OF IRREDUCIBLE SUBCUTANEOUS FRACTURES.
}

By JosePh RANSoHoFf, M.D., F.R.C.S., PROFLESOR OS ANATOMY AND CLINICAL BORGEEY, YSDICAL COLLEGE OF OHIO, CINCINNATI.

The henefits accruing from modern methods of conducting an operation are so constantly in evidence that their discussion at this time seems trite. Yet it is only hy keeping them in view that tentative suggestions in new fields can eventuate in things nccomplished. Therefore only would I allude to the safety to life and limh with which compound fractures are now trented. A death following a compound fracture from wound infection is now a rara avis, even in hospital wards that are far from surgically clean. Barring the paramount danger of infection and its sequel, necrosis, there are factors which would render the prognosis as to restitution to the normal in compound fractures quite as good, if not better, than in those uncomplicated hy a broken skin. The directness hy which fragments can he moulded into position and retained by sutures, if need be, the ease with which intervening muscle or memhrane can be removed, and the certainty with which an hxmatoma can be avoided at the site of injury, are data which, were it not for the danger of infection, would make the greater almost to he preferred to the lesser injury. So has the treatment of compound fractures heen hettered hy the grace of modern methods. In the absence of a like positive influence in the trestment of simple fractures, the results here ohtained, on the whole, are much as they were during the three decades intervening between the introduction of ansesthesia and antiseptic surgery. Except in fractures of the simplest varieties, we share with our predecessors the anxieties from incomplete reduction, deformity, shortening, and of partial or complete ankylosis in articular and pararticular fractures. In regard to these as a class, indeed, only two steps in advance have heen taken, and one of these is in the nature of a don't. 'There is an unanimity of opinion that hy prolonged immohilization joint-function is jeopardized. To effect the hest functional use of a joint " there must he a proper halance hetween rest and motion; rest of the hroken hone, motion of the joiut muscles, tendons, fascia. But eveu the methods to these ends are the suhject of much controversy." This is one step. The other, a very decided advance, has heen made in the method of overcoming shortening in exceptional cases hy tenomyotomy. Its range of utility has heen widespread since Dieffenhach first divided the triceps for fracture of the olecranon. Division of the tendo Achillis, the hamstring tendons, and of the sterno-cleido-mastoid may he done when it is evident that muscular contraction alone is responsihle for the shortening or 
deformity. In this connection it is amusing hy way of contrast to quote from Ricard on Fractures. In 1890 he wrote: "It is useless to add that to day no one has recourse to tenotiony; not on account of the terrihle mortality which Malgaigne had forty yenrs ago-three deaths in five cases-hnt hecause tenotomy has hecome superflnous since anæsthesia and continuous extension nre used in the overconing of muscular contractions."

Cases are encountered in which ansesthesia, extension, nnd tenotomy combined will fail to reduce deformity, and in which we seem helpless to prevent an unsatisfactory result. Aside from fractures of the patelln and of the femoral neck, wherein nnatomical data for bony union are deficient, we are wont at times to eee results far from good in fracture of the lower end of the tibia, of the femoral shaft, of the lower epiphysis of the femur, of the radius, of the elbow, and of the clavicle. The use of the cathode ray, where fessible, will douhtless tend to lessen the frequency and extent of post-fracture deformities by making easier the apposition of fragments. Yet there will be cases in whicb a clear picture of the lines of fracture will avail but little or nothing in the tberapy. The interposition of muscle, ligament, or fascin, or of a loose fragment of bone in the line of fracture will, at times, prevent its reduction and from the very heginning forbode a result dreaded in proportion to the dcformity entailed and its ensuing limitations of motion. In view of the successes now almost uniformly achieved in electivc operations on the bones and joints, the question migbt well be discussed, whetber, in otberwise irreducible simple features, early operative intervention sbould be refrained from. Such has been the eurgical teaching of the past.

Even very recent writers are silent npon the subject, and the consultant would find little or no justification in converting a recent subeutaneous fracture into an open one to ohtain a permanent hetter result. Nevertheless, individual points bave been made in this direction : by Senn, in the direct fixation of fragments in injuries of the hip, hy McBurney in fractures of the humerus complicated by dislocation, and very recently hy J. W. Hearn (reported hy Spencer), in tbe suturing of the hroken clavicle. An unique position in the immedinte operative therapy of fractures is occupied hy the patella, fractures of which have oftęn enough heen united to render a verdict against immediate interference. Since it was my privilege, in 1891 , to see Schede overcome a four-inch shortening of the femur from ohliqne fracture six months after the injury, I have believed that in certain cases an interference before union had resulted would be preferahle to the certainty of deformity. The cases in which operation would be indicated are necessarily fow. Nevertheless, seven cases have come under my ohservation in 
which the fracture was exposed and directly treated. I beg to suhmit hrief histories of these cases:

Case I. William F., aged twenty-four years, single, German ; heerwngon driver, admitted to the Good Samaritnn Hospital May 1, 1892.

Diagnosis. Fracture of the lower end of the right tihia. In jumping to keep a hrick wall from falling on him he landed full on his feet, hut his right nnkle turned, producing a fracture of the lower end of the tibia. The condition presented made the exact nnture of the lesion difficult to determine. There was a very extensive hæmatomn ahout the ankle, very great widening of the joint, with crepitus easily felt. Under the extensor tendons helow the line of the joint, surrounded by nn hrematomn, could he felt the loose fragment, which seemed to bave the shnpe of the articular portion of the astragalus. Under anasthesia every effort was made to hring this portion of hone into its normal relation hetween the tihin nnd fihula, hut without success. A long anterior incision was, therefore, made over the joint and the loose piece of bone removed. It proved to he the outer portion of the tihin. It was pyramidnl in shnpe, and the hase was covered with cartilnge. It measured nn inch and $a$ half in length nnd balf an inch in thickness et its widest pnrt, nnd evidently came from the articulnr end of the hone. Except for a small strip it was entirely detached. Through the incision the frncture of the lower end of the fihula was recognized. All clots having heen removed, deep sutures were resorted to, the external wound partly filled with gauze, nnd retentive dressings npplied. The first dressing remnined in position ten dnys, and when it was removed showed the wound was dry. Second dressing applied on the twentieth day. When this was removed, on the thirtieth dny, the joint was freely movahle, nnd the splints were left off excopt at night.

June 14th. The splints were finally left off, and the pntient was ahle to henr his weight upon the foot. Only slight impnirment of ankle movement.

20th. Patient dischnrged well, walking without crutch or cane.

CASE II.-John H., aged six years. (Reported with permiasion of Dr. Krouse, in whose service the case occurred.) November 19, 1895, patient was thrown from n street car, sustaining a compound comminuted frncture of the right leg, and what at first seemed to he an insig. nificant injury of tbe lower portion of the left thigh. There was a good denl of contusion here, nnd quite an extensive hæmatoma. The condition of the right leg necessitated immedinte amputation below the knee. During the recovery from the amputstion, which did not unite hy first intention, the hæmntoma in the lower portion of the left thigh disappenred nnd revealed an epiphyseal separation nt the lower end of the femur. It was evident thnt the epiphysis was tilted upward and forward, and that the lower end of the shaft was protruding into the poplitenl space, where part of its lower square surfnce could be clearly mapped out. The leg was retained in flexion with weight extension, in the hope of reducing the dislocation. The general condition of the patient did not justify an operative interference until December 30th, when an open incision was determined upon. An incision nhout three inches in length made in the mid-line of the popliteal space very readily exposed the transverse line cf separation. The square surfice of the shaft, without nny adherent cartilage, was readily laid hare. The upper 
surface of the epiphysis, with its cartilaginous covering firmly adherent, had been tilted forward so that it was found to rest ngainst the anterior surface of the upper fragment. Callus had not been thrown out. Extension failed to relieve the dislocation, even after the division of the nearest hamstring tendons. It was only after half an inch or more of the lower end of the femoral shaft had been chiselled away thnt the epiphysis could be tilted on its axis to a degree permitting npproximation of the surfaces. After hemostasis had heen cared for, the wound was tightly closed except for silkworm-gut drainage. The leg was dressed in right-angle flexion.

During seven days after the operation it nppeared as though primary union would result. This, however, was not accomplished, for the evidences of infection were seen on the ninth day, when the dressings were changed. Stitches had to he removed, since there was some suppuration.

The subsequent history of the case was that of ordinary infected compound fractures. The suppuration, which was at first extensive, gradually suhsided, and that without aecrosis. The patient was admitted to the Jewish Hospital on Novemher 19, 1895, and remained in the institution until May 29, 1896, when he was finally discharged well.

This patient attends school regularly. In its growth the femur has kept puce with its fellow of the opposite side, although a sinus has formed, which I have heea informed leads to a small sequestrum.

C.ASE III.-H. P., male, aged forty-three years, admitted to the Jewish Hospital Jure 5, 1892. Sustaired a fracture of the right radius six weeks hefore admission. There are characteristic silrer-fork deformities and rudial abduction. The fingers are flexed, while extension of the fingers and wrist is limited. Pararticular flm cedema is very marked. During two days the arm and hand were retained ia suspension to rcduce the swelliag. It was thea evident that reduction had aot heen accomplished, although a large callus had beea thrown out. The dorsal promiaeace of the lower fragment was very decided.

Operation, June $6 t h$. An incision three inches in length was made along the outer horder of the radius between the extension muscles of the thumb down to the hone. The periosteum was readily lifted from the callus. This was spongy and easily removed with eaw and chisel, therehy clearly exposing the line of fracture. No evidence of impaction was found. Efforts nt reduction failed until the hone was transversely divided with the chisel in the line of fracture. A reduction was then easily nccomplished and the fragments retained in place. The wound was closed except for a small gauze drainage to care for the rather copious oozing. The nrm was suspended during the first twentyfour hourz after the operation.

The subsequent history was uneventful. After three weeks nll dressings were dispensed with, and passive motion instituted. A supraarticular line of tendemess could be discovered, hut there was no deformity. When the patient left the hospital, gix weeks after operation, wrist movement was somewhat limited in dorsal flexion, and there was slight limitation of extension movements at the terminal digital phalanges. For all ordinary purposes the range and strength of motion of the fingers in flexion were normal.

CASE IV.-R. S., aged sixteen years, admitted to the Good Samaritan Hospital Jaly 6, 1893. Four weeks ago from a fall patient sustained a fracture of the right radius. Efforts were made in the country, where 
the accident occurred, to reduce the dislocntion, hut evidently without success. Splints had heen used almost continuously since the arcident. The nrm presented the typical deformity of a Colles's fracture, with impnirment of motion in the thumb, index, and middle fingers, due to hinding down of the tendons within the tendon sheaths. Point pressure over the site of the fracture was exceedingly painful. Under anzesthesia an effort was made to reduce the dislocation, hut without success. An incision was, therefore, made along the outer horder of the radius, three inches in leagth, and the fracture thoroughly exposed. There was no attempt at uaioa. The line of fractare was readily discerned, and an impaction easily recognized. It was only after the hone was divided in this line with the chisel that reduction could he effected, and the deformity readily removed. The entire wound was closed withont drainage, and the recovery was nn uneventful one. Passive movements were commenced two weeks after the operation. The patient was discharged from the hospital six weeks after the operation with practically normal function of the wrist and finger movement.

Case V.-R. F., aged niac years. Family history good; numitted to the Jewish Hospital Decemher 26, 1895 . On Septemher 25th was rua over by a hicycle and the right fenur fractured a little helow its niddle. The fracture was very ohlique, and shortening two and one. half inches. In the very heginning the case was treated hy weight extensioa and lateral spliats. Efforts at reduction made a week after the accideat under anrsthesia failed to reduce the shorteaing. After six weeks the union was quite firm, with marlsed outward howing. Shortening between two nad one-half and three inches.

Operation, January 2,1896 . Incision five inches in length from the outer portion of the thigh over the site of fracture. Hæmatoma had entirely disappenred. The fracture was very oblique. The fragments which had pussed each other were united hy a hridge of new bone. With considerable difficulty this was severed with the chisel. The medullary cavity of the upper fragment was closed by callus, the lower was still open. The upper fragment was freshened by the suw. A Senn hone-ferule, largest size, was now introduced and the fragment brought into good positioa. Silkworm-gut draingge was resorted to, except for which the wound was tightly closed. A final recovery from the operation in this case was satisfactory in the extreme. Except during the first three days the temperature did not exceed $101^{\circ}$, nfter which it returned to the normal and continued so throughout the stay nt the hospital. A fenestrated plnster-of-Paris dressing was applied immedintely nfter the operation and retained in place six weeks. The patient left the hospitnl with the wound perfectly healed, on March 1, 1896. After he left the hospital some pressure necrosis from the ferule resulted. This was removed hy Dr. E. W. Walker. The patient now, I uaderstand, has a shorteniag of less thn oae inch, and walks with only a perceptible limp.

CABr VI.-G. M., aged thirty-three years, admitted to the Ciacinunti Hopital Muy 12, 1896. Putient was in the hospital a year ago for delirium tremens. On the day of admission was run over hy a stone wagon, sustaining fructure of the leg.

Physical examiaation reveals a fracture of hoth hones of the right leg midway hetween ankle and knee-joint. At the site of fracture there is a well-marked nngle with on tward opening. The foot itself is inverted, 
toes pointing toward arch of opposite foot. Very considerahle hrematoma at the site of fracture.

Under anmsthesia efforts at reduction were made. It is evident that a loose fragment intervened at the site of fracture, preveating reduction. Dr. Evans assisted.

Under A. C. E. anzesthesia, nn incision three inches in length was made over the site of the fracture, from which a large quantity of hlood exuded. When the fracture was thoroughly exposed a spiculum of hone one-third of nn inch wide nnd over an inch in leagth was found wedged hetween the main fragments, which could not be hrought into apposition until the interveniag spiculum was removed. Reduction was then easily accomplished. The entire wound was tightly closed in the hope that primary unioa would result. This was evidently a mistake, for suppuration ensued withia n week, necessitatiag the removal of the stitches. Some necrosis of the hoae resulted, so that on July 18th n secondary operation with bone sutures had to he made.

The patient was finnlly discharged with n sound leg, wnlking withou $t$ cane and with less than oae inch shortening.

CASE VII. - A P, aged thirty-eight yenrs, ndmitted to the Cincinaati Hospital Decemher 22, 1896.

Present history. On date of ndmissioa patient received a gunshot wound of the forehead and of the left nrm. Whea admitted she had recovered from shock. There was considerahle hemorrbage from wound in the forehead, and she was unable to use the left arm. The round of the forehead was a scalp wound and of no significance. On the outer side of the left arm ahout two inches below the ncromion process was found the wouad of entrance, probably made by a 38-calibre ball. Crepitus is felt if the arm is moved, and the head does not rotate with the sliaft. Aa aseptic dressing was npplied and external spliats over extension. Both wouads in the scalp and in the nrm healed by first inteation.

January 16th. No evidence of union in the fractured humerus. A radiogruph takea shows an ohlique fracture nhout four inches below the shoulder-joiat, with the lower fragment passing upward along the outer surface of the upper. The hullet is seen flatteaed ngainst the inaer side of the upper fragment, having evidently passed through the bumerus.

$18 t h$. Under chloroform anasthesin nn iacision three inches long was made along the outer surface of the nrm, by which the fracture was exposed. Between the fractured surfnces an uaorganized hlood-clot adherent to shreds of periosteum was found and readily removed with curette. The hullet was removed. When extension was npplied the fragmeats were ensily hrought into npposition nud retained hy a wire suture. The wound wns eatirely closed hy deep nad superficinl sutures.

The suhsequent history showed nn infection, which was limited to the soft parts nud was readily relieved hy removing a few of the sutures. The patieat was discharged on March $3 d$. The hones had uuited hy a lnrge mass of callus; arm fuaction practically normal.

ReMarks. Though the cases reported nre few they are of sufficieat diversity in regard to regioal distrihution and time of interfereace to wnrrant some general conclusions.

In two of the cases interference was immediate, and in two osseous union had occurred. In one of the cases of immediate operation sup- 
puration resulted, whereas in the other complete primary union took place. In only two of the cases in which operative interference was delayed did suppuration result. The inference may possihly he drawn hcrefrom that early interference predisposes to infection. This can readily he explained hy the lowered vitality of the contused tissues and their notahly reduced resistance to infective processes. This inference is strengthened hy reports from many surgeons who have resorted to direct mechanical appliances for firation of fragments in compound fractures or for the cure of pseudarthroses. I would only refer to the cases in which Senn used the hone ferale and Bircher the ivory plug. Nevertheless, since in all of these cases, by the interference plus the infection, the end result was hetter than it would probahly have heen without operation, the patients were hrought only into the condition of one who had primarily sustained a compound fracture.

The lesson is plain, however, that extraordinary precautions toward securing asepsis must be taken before the simple is deliherately converted into a compound fracture.

Of fractures through the epiphysis two cases are recorded, one of the lower end of the radiug, the other of the femur. Both of these cases were operated upon before callus had been thrown out.

In two cases operation was delayed until quite firm union had beeu effected. The operations were, therefore, for vicious union. Although nature does much to cover the inequalities left from the fracture, in neither of these cases would a good result have been obtained without operation. The question is, therefore, pertinent, if when deformity is certain to follow fracture it is not hetter to wait until union has taken place. Aside from the douhtless greater danger from infection in immediate operations, no strong argument can be advanced in favor of delay. Particularly is this true in epiphyseal separations. In those of the lower end of the femur the danger to limb and even to life from cumpression of the vessels is very great. An enrly interference can only he of advantage wherehy the production of deforming callus will be forestalled. The technical difficulties of operation hefore callus has formed are very much less than those which attend the operative corrections of vicious union after fracture. Such fixation of epiphyseal separation need not necessarily imply an open wound, since hy means of long pins driven through the skin, Helferich has recently succeeded in fixing the humeral epiphysis. The same procedure was employed several years hefore hy Lange, and the principle is that advocated hy Senn in fractures ahout the hip. It is very possihle that hy means of such a drill and with skiagraphic tracing of the fracture, say of the elhow or of the ankle, before him, an operator can transfix fragments without open incision and retain them in position hy means of the drill.

There are certain classes of cases in which open treatment should he

vor. 114, *o. 4-OCTOBEB, 1897. 
strictly ruled out, even if the deformity is great. In cases of crushed fracture, where extensive comminution can he made out, nothing could be gained from operative interference. Altogether, therefore, the cases in which the open treatment should he resorted to would be few and far between. Nor does the experience of the writer, or what he has gleaned from literature, warrant him in coming to conclusions that ure final. Nevertheless, he helieves thnt it would he justifiahle to suhmit in $n$ tentntive way the following postulntes:

1. The conversion of a simple fracture is justifiahle when other means to secure the hest end results fail.

2. In fractures of the diaphysis of the tihin, femur, humerus, nnd clavicle in which insurmountahle longitudinal displncement or nxinl rotntion has taken place, immedinte operation or medinte operatiou hefore definite union has ocenrred is indicated.

3. In epiphyserl separations, when reduction cannot he otherwise effected, an early operation is justified.

4. Fractures complicated with dislocations irreducihle hy other methods warrant operative interference.

5. The involvement of $n$ joint, except prohnhly in the case of knee and hip, do not, per se, militate against operation if this is otherwise indicated.

6. If extensive comminution is present, as in compression or crushed fracture, operation is contraindicated.

7. Special precautions against infection must he talken, in connection with which should he horne in mind the dangers of too firmly closing a rround and the advantage of temporary tamponsde and secondury suture.

8. Reckless and indiscriminate resort to the operative relief of deformity in recent simple fractures is to he condemned, since there would he few fields of surgery, in the event of an unsuccessful intervention, in which the contrast could he greater hetween the good intended and the harm done.

\section{ON THE VALUE OF ATHLETIC EXERCISE AS A COUNTER- AGENT TO THE SEDENTARY PURSUITS OF URBAN POPULATIONS.'}

By Sir Dyce Deck worth, M.D., LL.D., PHYEICIAN AND LECTOREA ON MEDICINE, BT. BARTHOLOMEW'B EOSPITAL, LONDOS; HON. PHYBICTAY to H. F. H., THE PERSCE OP WALES.

We often hear that a healthy mind can only he found in a healthy hody. This is $\mathbf{n}$ great fact. We too often meet with instances which illustrate the converse of this, and have no lnck of opportunity of wit-

In address delivered beforo the Birninghim Athletic Insutute. 